Article

\title{
Possible Selves, Body Schemas, and Sädhana: Using Cognitive Science and Neuroscience in the Study of Medieval Vaiṣnava Sahajiyā Hindu Tantric Texts ${ }^{1}$
}

\author{
Glen Alexander Hayes \\ Department of Religion, Bloomfield College, 467 Franklin Street, Bloomfield, NJ 07003, USA; \\ E-Mail: Glen_Hayes@bloomfield.edu
}

Received: 27 June 2014; in revised form: 19 July 2014 / Accepted: 25 July 2014 /

Published: 5 August 2014

\begin{abstract}
In recent decades, historians of religions have turned to, and developed, entirely new methodologies for the study of religion and human consciousness. Foremost among these are a collection of approaches often termed the "cognitive science of religion" (CSR), typically drawing on cognitive science, neuroscience, linguistics, and contemporary metaphor theory. Although we are still "early" in this enterprise, I hope to show how a meaningful dialogue between religious studies and contemporary neuroscience and cognitive science can help us to better understand some intriguing mystical texts and practices from a tradition of medieval South Asian Hinduism. Known collectively as the Vaișnava Sahajiyās, these followers of transgressive and antinomian Tantric Yoga provide excellent examples for exploring the nature of religion, ritual, consciousness, embodiment, identity, gender, emotions and sexuality. This paper will show how the study of these rich materials from 17th through 18th century Bengal in northeastern South Asia can be enhanced using insights from the philosopher, Shaun Gallagher, and the neurologist, Patrick McNamara.
\end{abstract}

Keywords: Tantra; Yoga; Sahajiyā; neuroscience; cognitive science; sexuality; gender; embodiment; emotions; self

\footnotetext{
A version of this paper was presented at the International Workshop on Buddhism and Science, 14 April 2013 held at the University of Toronto, Scarborough. I extend my thanks to the convener Geoffrey Samuels, as well as to the Tung Lin Kok Yuen Foundation for their generous support which enabled the conference to happen. An even earlier version of this paper was presented in Chicago at the 2012 Annual Meeting of the American Academy of Religion (AAR), at a session co-sponsored by the Cognitive Science of Religion Group and the Tantric Studies Group.
} 


\section{Introduction}

These are interesting times for scholars involved in the history of religions, for entirely new forms of methodology are being developed for the study of religion and human consciousness. Foremost among these are various approaches often termed the "cognitive science of religion" (CSR) and also the range of disciplines known as neuroscience. Although we are still "early" in this enterprise (and this Special Issue of Religions is just one of many expressions of this collaboration), I hope to show how a meaningful dialogue between religious studies and contemporary science can help us to better understand some intriguing mystical texts and practices from a tradition of medieval South Asian Hinduism. Known collectively as the Vaiṣnava Sahajiyās, these followers of transgressive and antinomian Tantric Yoga provide excellent examples for exploring the nature of religion, ritual, consciousness, identity, gender, and sexuality. This paper will show how the study of these rich materials from 17th through 18th century Bengal in northeastern South Asia (approximately modern-day West Bengal and Assam in India, as well as parts of Bangladesh) can be enhanced using insights from the philosopher, Shaun Gallagher, and the neurologist, Patrick McNamara. Before considering the cognitive science of Gallagher and the neuroscience of McNamara, a brief overview of the Vaiṣnava Sahajiyās and their texts will illustrate why I am intrigued by these recent insights and how these approaches may enhance the developing dialogue between the humanities and the sciences. My own stance is to avoid simple materialism and reductionism, and to suggest that, beyond a basic reading of these complex mystical texts we can discern what might have been happening to their authors and practitioners on a neurobiological level. Again, this is but an early step in such a scholarly effort, but I think that the results are promising.

\section{The Vaiṣnava Sahajiyās and their Texts}

I was trained as an historian of religions at The University of Chicago, where I focused my studies upon first Hinduism, then on Hindu Tantra. While scholars still debate the category and nature of Hindu Tantra, ${ }^{2}$ here it is sufficient to say that it is an ancient form of Hinduism which incorporates diverse strands of philosophy, ritual, contemplation, and sexuality in order to achieve a transcendent embodied state. There are dozens of forms of Hindu Tantra, dating back to as early as the 4th century $\mathrm{CE}$, but the version I ended up studying goes back to no earlier than the late 16 th century. Their texts were composed in an enigmatic and obscure form of medieval Bengali, with some verses in Sanskrit. The Vaiṣnava Sahajiyās, in brief (more details below), were a secretive Hindu tantric appropriation of the better-known "Caitanya movement" or "Bengali" (Gauḍiya) Vaiṣnavas. Caitanya lived from 1486-1533 CE, and he triggered an ecstatic emotional wave of religiosity (bhakti) throughout northern India involving the worship of the Hindu deity Kṛṣna and his divine consort Rādhā. But some of his most devout followers worshipped Caitanya himself as a type of "dual incarnation" of Kṛ̣na and Rādhā in one body, a situation which the devout saw as enabling the most intense form of "divine love" (prema) possible.

Very intricate theological, philosophical, and ritual systems developed around Caitanya, and the orthodox devotional movement he inspired continues to live on, with many devotees still traveling to

2 See, for example, my own bibliographical discussion of Hindu Tantra [1]. 
West Bengal and to the region of Vraja in western India along the Yamunā River (where some of the original mythical exploits of Kṛṣna are believed to have occurred). Gauḍiya Vaișnavism focusses on performing devotional ritual practices (bhakti), such as dancing and singing praises (kirtana) to the Hindu god Kṛṣna, regarded as the ultimate godhead and supreme being [2]. Many of their stories derive from the Purānic traditions, especially the Bhāgavata Purāna, including the many tales of the erotic exploits of Kṛṣna with the young milk maidens (gopiss, regarded by the orthodox as the human soul). Kṛṣna's favorite lover is Rādhā, and the later theological and philosophical developments take this dualistic theological system in quite complex directions. The basic cosmology is one of layered realities, involving the assumption that the divine love-play (līlā) of Kṛṣna and Rādhā did not only occur in some mythological "past", but in fact is constantly taking place in a celestial realm known as "eternal" (nitya) Vṛndāvana. The pure, divine love or prema that flows between Kụșṇa and Rādhā is indeed salvific, as devotees may spend years yogically creating a "maiden body" (mañjarī-rūpa) so that they, too, may tenderly if vicariously "participate" in the līla and prema-ending in salvation as a supporting character in the eternal realm of Kụṣna. (For Buddhists, this would be roughly similar to seeking rebirth in Sukhāvatī or a Buddha-kṣetra.) But the tantric Vaiṣnava Sahajiyās made significant adaptations to this orthodox devotional system, as we shall see.

Whereas the orthodox Gauḍiya Vaiṣnavas regard Kṛṣna as the supreme divinity and Rādhā as his divine lover, the Vaiṣnava Sahajiyās change this to make Kṛ̣ṇa the underlying male principle in each man, while Rādhā is the inner female essence of every woman. In other words, the Vaiṣnava Sahajiyās developed a very human-centered version of the divine couple, much to the chagrin and outrage of orthodox Gaudīya Vaiṣnavas throughout the centuries. Although there were pre-Caitanya Buddhist traditions in Bengal in which "sahaja" (literally, the "Together-born," glossed as "Innate", "Spontaneous", "Natural") was a goal (e.g., the Siddhācāryas), the Vaiṣnava Sahajiyās were very likely only a post-Caitanya development. As secretive Tantrics (possibly living a "double life" as orthodox Gaudīya Vaiṣnava practitioners) and since they risked expulsion and opprobrium for violations of caste and ritual purity from the conservative Bengali village societies during the 17th through 19th centuries in which they lived, virtually all of their surviving texts are written in an especially opaque style of medieval Bengali. Although much of their vocabulary is derived from the Gauḍiya traditions (with some also from the Nāth and Siddha traditions), the language is largely uninflected, meaning that translation of any line is tricky. This lack of inflection makes us unsure of precise verb conjugations, the declensions of nouns and adjectives, and other grammatical nuances that are quite refined in other Hindu tantric traditions. ${ }^{3}$ In a line of eight words, we may have to guess what the direct and indirect object are, and the verb tense might only occasionally be added to help with rhyming and meter. Enough of the material is clear enough to get a general sense of what is going on (usually details of rituals and visualizations), but a fair amount is not.

At any rate, for my doctoral dissertation [3] I traveled to West Bengal in 1979 and 1980, where I photographed and hand-copied manuscripts at Visvabharati University in Santiniketan, and at the University of Calcutta and Bangiya Sahitya Parisad archives in Calcutta. I also conducted fieldwork

In a recent email, Geoffrey Samuel observes that "something like this happens in Tibetan, where the equivalent of inflections (grammatical particles that generally follow noun- or verb-equivalents) are often omitted in verse, making it quite difficult to work out exactly who is doing what to whom." 
among the closest direct descendents of the medieval Sahajiyās, known as the Bāuls and Kartā Bhajās. It was a handful of Bāuls whom I interviewed at a big festival (the Dol Mela at Ghospara) who confirmed that some of my translations of very technical terms were probably correct, ${ }^{4}$ and I ended up leaving India with hand copies and photographs of several texts attributed to the Siddha Mukunda-deva (ca. $1600 \mathrm{CE}$ ) and his school, as well as several dozen other Sahajiyā manuscripts. (Manuscripts were carefully photographed only when allowed by cautious archivists. There are stories to tell about this process!)

Most Vaiṣnava Sahajiyā texts are difficult to translate, let alone understand, for it seems that they were to be clarified (essentially given the missing grammatical inflection) only by the oral commentary by the living gurus. Unfortunately, these gurus seldom wrote down their commentaries (which is standard and often extensive in most other Hindu Tantric traditions such as the Saiva schools of Kashmir and in Sākta Tantra). Furthermore, neither Dimock [4] nor I were ever able to locate and interview an apparently authentic Vaiṣnava Sahajiyā guru (The great Bengali scholar Ramakanta Chakravarti confirms this modern absence of "genuine" Sahajiyās.) ${ }^{5}$ The late Carol Salomon [9] and, more recently, Jeanne Openshaw [10] have done great studies of the Bāuls, and Hugh B. Urban [11,12] has done fine work on another of the later groups associated with the Vaiṣnava Sahajiyās, the Kartā Bhajās. For my doctoral thesis [3], I was able to successfully articulate some Vaiṣnava Sahajiyā systems of the yogic body (dehatattva), but much remained to be translated, and over the past few decades I have continued to translate selected texts. Some of these have appeared in the Princeton Series on Readings in Religions, including Religions of India in Practice [13], and both Tantra in Practice [14] and Yoga in Practice [15].

Over the years, I realized that the traditional tools of the historian were inadequate for the study of these texts, and I turned increasingly to methodologies in the areas of linguistics, semiotics, cognitive science, and, most recently, neuroscience. At first, what truly helped me to better translate and understand Vaiṣnava Sahajiyā texts was the use of the "conceptual metaphor theory" (also known as "contemporary metaphor theory") developed by George Lakoff and Mark Johnson [16]. I was also helped by the argument of my friend and fellow Bengal-studies scholar Tony K. Stewart that even an uninflected text like the Necklace of Immortality (Amrtaratnāvalī; ca. 1650CE) by Mukunda-deva's disciple, Mukunda-dāsa, could be translated to reveal the "coherent metaphoric world" that the author was working with. For example, the Sahajiyā system of the yogic body differs somewhat from that of most Śaiva and Śākta Hindu tantras in that it does not consist primarily of cakras ("wheels") or Kuṇụalinī (serpent energy). Instead, reflecting the actual riverine environment of deltaic Bengal, it consists of a series of ascending "lotus ponds" (sarovara; within which there are lotuses and cakras) which convey yogically-reversed sexual fluids along an inner "crooked river" (bāinkānadī). Without

4 This recognition was much to their surprise, and to my relief. As a definite outsider and foreigner, the Bāuls gathered for the festival were amazed that I could speak some halting Bengali, and had a working knowledge of the texts. The term that I figured out, vastu, can often be translated as "thing" or "truth" in conventional Bengali; for Sahajiyās and Bāuls however, it is a "code word" for the sexual fluids (rasa/semen, rati/uterine fluid) believed to be gathered during ritual sexual intercourse. This helped to further our subsequent discussions regarding religion, consciousness, sexuality, and embodiment — to say the least.

5 Personal conversations in 1979-1980, but see [5] for his overviews of Bengali religion. For some earlier studies of the Vaiṣnava Sahajiyās, see [6-8]. 
getting into the details, suffice it to say that translating with an eye to the larger metaphoric world did help me to clarify more of the murkiness of Vaișnava Sahajiyā texts.

But not quite enough, and this led me to make the additional use of an extension of metaphor theory known as "conceptual blending theory", based on the wonderful volume by Gilles Fauconnier and Mark Turner, The Way we Think: Conceptual Blending and the Mind's Hidden Complexities [17]. In studying metaphors, one notices that there are various "entailments" or nuances of metaphors that may occur in some situations, but not others. Such details and nuances matter when translating a difficult and nuanced visualization manual such as the Necklace. Fauconnier and Turner show how the traditional metaphors studied by Lakoff and Johnson are what they call "single-scope blending", in which the "frame" or organizing principles from one domain (the "source" domain such as "war" in the ARGUMENTS ARE WAR metaphor) is projected onto another domain (called the "target" as in "argument", which we hoping to clarify by using the metaphor). In their book, they show that there are in fact many cases far more complicated than a single-scope metaphor or "blend", and that humans employ "multiscope blends" in which some parts of different "domains" are projected, but not others. So this leads to what they call "emergent structure": a concept or trope that occurs only in the blend, and makes sense only in the blend. A quick example is the notion of the "computer desktop", in which selected aspects of the domains of office work, computer programming, and spatial relations are blended to create the familiar "desktop" that we all work with. The value of this theory is that it allows us to better understand the richness and complexity of the religious language, visualizations, rituals, and cosmographies that are presented in Sahajiyā texts. I have presented papers on this at the Annual Meeting of the American Academy of Religion (AAR) in Montreal in 2009 and at the Society for Tantric Studies (STS) meeting in Flagstaff in 2010, which were eventually published in the Oxford Journal of Hindu Studies [18].

Despite this relative "advance" in translation methodology provided by blending theory, my discussions with AAR colleagues such as Kelly Bulkeley [19,20], and my involvement with the Cognitive Science of Religion unit have propelled me towards using more cognitive science and neuroscience. In this essay I would like to summarize my initial explorations using two works in this area, and suggest how they may help to bridge the worlds of religious studies and cognitive science and neuroscience.

\section{A Philosopher Using Cognitive Science: Shaun Gallagher}

One work which I have consulted is the interdisciplinary work by Shaun Gallagher, How the Body Shapes the Mind [21]. While Gallagher is not himself a neuroscientist, as a philosopher he combines analytic (Dennett) and continental (Merleau-Ponty) philosophy, clinical neurology, laboratory neuroscience, cognitive psychology, and developmental psychology. One of his major "take-away" points is that we are now at a moment in the development of the cognitive science of religion (CSR) where we need to develop a "new vocabulary" to express what we are learning. (Publications like this Special Issue of Religions should indeed help with this process.). Gallagher explore the very dynamic issues of proprioceptive function as a subpersonal or "prenoetic" experience versus conscious experience. For me, this promises insights into how somatic proprioception can be applied to Vaiṣnava Sahajiyā and Gauḍiya Vaiṣnava ritual practices (sādhana) or concepts of the yogic body ("metaphysics 
of the body," dehatattva). Some of Gallagher's insights may be traced back to Mark Johnson's earlier work The Body in the Mind: The Bodily Basis of Meaning, Imagination, and Reason [22], especially his concern for internal "body schema" that structure human experience. Gallagher identifies body image as "a system of perceptions, attitudes, and beliefs pertaining to one's body", while body schema is "a system of sensory-motor capacities that function without awareness or the necessity of perception-monitoring" ([21], p. 24). This set of capacities may be applied to sādhana and dehatattva as these are processes of sequentially modifying not only the adept's conscious body image but also - through the "remembrance" (smaraṇa) of one's "forgotten" identity as either Kṛ̣ṇa or Rādhā (for the Vaiṣnava Sahajiyās) or as one of the milk-maidens (gopīs, mañjarī, for the Gauḍiya Vaiṣnavas), and through the practice of āropa-sādhana ("attribution") of one's deeper "true identity (svarüpa) to one's worldly form (rüpa) — of transforming the usually prenoetic "capacities" of the body schema. Thus, the interiorized "divine" or yogic body of the maiden requires extensive amounts of visualization and ritual, as well as sensory modifications in order to trigger mirror neurons and relevant neural networks associated with visual, tactile, olfactory, and emotional centers. The fact that both Gaudīya and Sahajiyā system involve intensification of the emotions, and the advanced stages of Sahajiyā sādhana, called "rati-sâdhana", literally "practice with a desirable woman" involves ritual sexual intercourse would seem to be powerful methods for modifying the body schema. Thus, from Gallagher's perspective, we can see that sādhana results in the gradual change in not only the conscious body image, but in the prenoetic body schema.

In recent email exchanges with my colleague Gavin Flood at Oxford University, he informed me about the growing field of "second person" or "social neuroscience", in which the dynamics of cognition and neural states are influenced by the presence of one or more persons. In other words, studying the brain in the presence of another brain may lead to different findings. This certainly has implications for much of Tantric ritual, especially the sexual sādhanas like rati-sädhana, where the body schemas of a male and a female are in quite intimate contact. Again, through the process of $\bar{a}$ ropa-sādhana, the male rüpa-body becomes the svarūpa-body of Kṛ̦na, while the female rūpa-body becomes that of Rādhā or one of the gopiss. Even in the orthodox versions of mañjarī-sādhana, as shown by David Haberman [23], male practitioners are assigned by their guru a specific gop $\bar{\imath}$ from the narrative of the Kṛṇa story, and they sing and dance as her, including in some cases rituals in which male devotees wear saris. It seems to me that this not only results in a different body image, but in the even deeper shifts in body schema - and hence experience. Gallagher argues ([21], p. 27) that "a body schema contributes to and supports intentional action". This has implications for advanced ritual practices at the more-advanced levels of sädhaka ("accomplished") and siddha (perfected") in three-stage Sahajiyā sädhana as presented in the Necklace of Immortality [14]. This may be because a schema is "a prenoetic performance of the body" and "helps to structure consciousness" ([21], p. 32). Some selected passages from the Necklace illustrate this dynamic [14]:

18. The three stages of practice are called: Beginner (pravarta), Accomplished (sädhaka), and Perfected (siddha). These correspond to three states of consciousness: Divine Existence (bhāva), Divine Essence (rasa), and Divine Love (prema).

19. When you are initiated and receive your mantra, the guru will protect you. While in the Beginner's stage, your practices involve the use of your physical body. 
20. The kinds of practices appropriate for the physical body consist of the sixty-four types of ritual devotions developed by Gauḍiya Vaiṣnavas. Such ritual devotions have been written about and explained elsewhere.

22. As a Beginner, you must master these different ritual devotions. The consciousness of Divine Existence will continue as long as no Female Partner is actually present.

23. The sixty-four types of ritual devotions are intended for the Beginner and the physical body. Devotions which are influenced by worldly karma should be avoided by the Adept.

25. At the moment one receives a mantra, one also joins the spiritual lineage of the guru. After this initiation, however, you must continue your practices under the guidance of a teaching guru.

26. Through such further practices, the Adept will develop the finest physical body. Even older men and women can benefit from the consciousness of Divine Existence.

27. A Divine Body (devadeha) must be born within the physical body. So how may men and women become conscious of such a Divine Body?

28. With effort, you will discover the Divine Body within the physical body. By following the teachings, one produces the Cosmic Substance of the Divine Body.

29. By performing practices with a woman, the Divine Body will appear within the physical body. A woman with special inner qualities should serve as the passionate Female Partner.

30. When both the male and female principles are brought together within the physical body, then the advanced practices leading to consciousness of Divine Essence and Divine Love may be performed.

Gallagher observes ([21], p. 35) that one may use "a consciousness of bodily movement to train body-schematic performance", and this would seem to be born out in the cited passage. The sixty-four ritual practices referred to in the passage are the first stage of Gauḍiya Vaiṣnava sādhana, known as "vaidhi" or "external" ("rule-based") bhakti. These may involve simple worship of images of Kṛ̣na and Rādhā, dancing, and singing praises (kīrtana). And while the higher form of Gauḍiya worship as a "maiden" takes place in the advanced stage of rāganugā ("passionate") bhakti sādhana, for Sahajiyās it takes place at the stages of sādhaka and siddha. Echoing Gallagher's categories, the Sahajiyās distinguish the beginner's stage as "external" (bāhya), while the higher stages are "interiorized" (antara, marma, gupta). More broadly, this use of bodily movements to affect deeper consciousness can be seen in the classical stages of Patañjalin Yoga, where practice and mastery of prānāyāma is one of the methods for achieving the higher and deeper states of consciousness and (in some schools) the yogic body. By controlling what we can in ritual (body, breathing), we gradually activate and connect neural networks that result in an entirely "new" body schema, e.g., one involving cakras, nā dīs (subtle body channels), and inner realms. In summary, sādhana using dehatattva involves a type of "retraining" of ordinary body schema into one of lotuses, channels, ponds, deities, mountains, and villages and which gradually goes from prenoetic consciousness to consciousness and hence part of conscious body image. This may not be "real" in a conventional "Western" or "modern" sense, but it is certainly experienced as a "sensory" or even neurobiological reality by the practitioner. Thus, ongoing research in the cognitive science of religion may help us to understand the neural correlates of such experiences. I would resist the materialist position of reducing such experiences to "just the brain", but this is an ongoing debate. 
The medieval Vaiṣnava Sahajiyās seem to be in resonance with the ideas expressed in Gallagher's citation of Lackner [24] that body schema depends upon "a collaborative interaction of multiple afferent and efferent domains" ([21], p. 36). Vaiṣnava Sahajiyā ritual practice is not only multisensory and based upon gendered bodies interacting, but requires the presence of the initiate community (sädhu-samgha) and the guidance of two types of gurus: the mantra-guru who imparts the empowered syllables, and the sílkșa-guru (mentioned in the passage above) who conveys the ritual practices. There are also graduated levels of "love" to be experienced and mastered, from the lower, lustful kāma to the higher, pure divine love of prema. Although today is not the place to explore this, the Sahajiyās also made extensive use of the Gaudīya theological refinements of classical Sanskrit rasa theory and dramaturgy, which categorized and connected the entire range of human emotions and perceptions known to them. In short, a play was intended to raise the experience of the "mood" (bhāva) of the play into the pure delightful essence ( $r a s a$ ) which could involve divine love (prema). When Sahajiyā gurus such as Mukunda-deva blended all of this with Nāth and Siddha sādhanas, you can see how complicated it could be.

In a future publication I will have more to say about Gallagher's useful insights that can be applied to the study of Tantric texts, but here it is enough to say that he has already made a solid contribution to the growing discipline of CSR. (I would also strongly recommend Edward Slingerland's wonderful What Science Offers the Humanities: Integrating Body and Culture, Cambridge [25].) But Gallagher acknowledges that there is still much work to do. As he observes ([21], p. 39):

We still need to show that these concepts [of body image and body schema] can do justice to the complexities of embodied cognition, or, at least, acknowledging their limitations, we need to show that they can carry us some distance in this direction, and how they can contribute to a more developed vocabulary of embodiment. To complete this task we need to continue our analysis by proceeding to:

1. show how a consistent distinction between body image and body schema can further our understanding of embodiment;

2. provide a developmental account of the body schema and body image;

3. examine these phenomena in light of recent neuroscientific findings; and

4. show how these concepts are useful and clarifying for systematic explanations of pathological conditions.

Each of Gallagher's points seems attainable with the increasing cooperation and collaboration between scholars of religious studies and cognitive scientists and neuroscientists. His appeal for a useful "vocabulary of embodiment" is very important, for it seems that neuroscientists might be especially helpful in reaching this goal. In sum, Gallagher's work has raised important questions and brought forth valuable insights regarding the complexities of embodiment, especially as experienced in complicated mystical traditions such as the Vaiṣnava Sahajiyās.

\section{Views of a Neurologist: Patrick McNamara}

Fortunately, Gallagher's hope for the collaboration of a neurologist and neuroscientist has been met by Patrick McNamara, Associate Professor of Neurology at Boston University School of Medicine in 
his groundbreaking The Neuroscience of Religious Experience [26]. McNamara is a gifted scientist, with extensive clinical laboratory experience, who combines neuroscience, evolutionary biology, and cognitive science in an effort to better understand the nature of religious experience. He does not reduce religion to pathology like some schools of psychology, nor does he simply reduce it to "brain processes". He is much more nuanced, and summarizes much empirical research and study in an accessible manner for determined non-specialists like me. His primary goal ([26], p. x) is "to contribute to the emerging cognitive neuroscientific study of religious experiences and practices". Although he focuses mainly on Western religious traditions and theism, we can still apply his insights to the study of Tantra. In fact, my argument is that his basic insights and paradigms can aid us tremendously in our own study of Vaiṣnava Sahajiyā sādhana and dehatattva.

In a way, McNamara provides us with the neurological systematics that operate "behind" Gallagher's concepts of body image and body schema. In short, his book ([26], p. xi) will introduce us to his findings that "The fact that a particular circuit of brain regions is consistently associated with religious experiences may tell us something about the nature and functions of religion." Refreshingly, he also adds that ([26], p. xi) "Whatever else it is, religion is an integral part of human nature and thus religion is not mere delusion." This, of course, is contrary to some older Freudian interpretations of religion as a "childhood neurosis" (applicable as it may be in some selected circumstances, but not globally). Without getting into the varied and rich details of the neurological structures and biochemistry that he summarizes in his book, it is worth citing his opening overview ([26], p. xi):

The functionally integrated religion-related brain circuit involves a widely distributed set of neural regions (depending on particular religious behaviors) but nearly always includes the key nodes of the amygdala, the right anterior temporal cortex, and the right prefrontal cortex. Sometimes the subcortical amygdala is not part of the picture, but the hippocampus is. Sometimes one portion of the prefrontal cortex does not "light up" in association with religious practices, whereas another region of the prefrontal cortex will. Sometimes the parietal lobes are implicated, and so on. Nevertheless, in hundreds of clinical cases and a handful of neuroimaging studies, it is a striking fact that the amygdala, large portions of the prefrontal lobes, and the anterior temporal cortex are repeatedly implicated in expression of religious experience.

Beyond McNamara's demonstration that ([26], p. xi) there is an "anatomical overlap between the brain sites implicated in religious experience and the brain sites implicated in the sense of Self and self-consciousness" his use for the study of Tantric sädhana involves his argument that religious practices ([26], p. xi) "often operate to support transformation of the Self such that the Self becomes more like an 'ideal Self' that the individual hopes to become. This hoped-for Self is a more centralized and unified sense of Self". This is more or less exactly what Vaiṣnava Sahajiyās hope to achieve as they unify male and female bodies and energies in the hopes of achieving the ultimate interior transcendent state of the unified Sahaja-mānușa, the "together-born being", the innate cosmic androgyne which blends Kṛ̣na and Rādhā, and absorbs all of phenomenal reality. The process proposed by McNamara is intriguing, and I will provide a condensed version of his argument.

McNamara argues that human beings experience a range of "possible selves", each of which is connected to a specific neural network that can be modified by what he calls "decentering", allowing 
for a transformation into another "possible self" and ideally into a type of ultimate state that he calls the Ideal Self or Executive Self. Much of his book explores this basic process, and the many overlaps with religious experience. To begin with, he argues that ([26], pp. xi-xii) "religious practices contribute to the creation of a unified self-consciousness and an ideal 'executive Self". Furthermore ([26], p. xii):

Religions accomplish this feat by promoting a cognitive process I call decentering. In this cognitive process, the 'Self' (i.e., the Self-construct or the Self-concept) is temporarily taken "off-line" or decoupled from its control over attentional and behavioral goals of the individual while a search is conducted in semantic memory (or in a "possible worlds" space) for a more ideal or complex Self-concept that can better match the needs and behavioral goals of the individual.

Not only might the medieval Tantric gurus understand this, they might exclaim that this in fact is what their sädhanas do (allowing for differences in terminology, historical and cultural contexts, and worldview)! McNamara adds ([26], p. xii) that "decentering occurs in religious ritual contexts" and that "The ideal Self against which the old Self is compared may constitute a powerful ancestor, a saint, or a god." For Sahajiyās, of course, the Ideal Self would be the androgynous state of the Sahaja-mānuṣa, while for Gauḍiya Vaiṣnavas it would be the state of the mañjari maiden, forever blissful in her eternal support of the divine love-trysts of Rādhā and Kṛṣna in their heavenly realm.

Another incredibly useful insight made by McNamara is his observation that ([26], p. xii) "Story or narrative grammars help to integrate the old into the new Self." For both Gauḍiya Vaiṣnavas and Vaiṣnava Sahajiyās, the vast store of mythological traditions found in the Purānas concerning the līlās of Kṛṇa, the extensive subsequent retelling and elaborations of these tales by the gurus and the Gauḍiya Vaiṣnava theologians, as well as the hagiographies of Caitanya (e.g., the massive Caitanya Caritāmṛta of Kṛṣnadāsa Kavirāja; see the masterful edition by Dimock and Stewart [27]) would provide ample narrative material for this transformative process. In fact, many would argue that that is one of their reasons for being transmitted down through the ages: their soteriological, epistemological, and cosmological functions.

McNamara's research is of great value to the historian of religions as well as the CSR, for his process of the sequence of "possible selves" mirrors the different stages of Gauḍiya Vaiṣnava and Vaiṣnava Sahajiyā sādhana, and his "decentering" mirrors many of the transitional ritual processes and visualizations of inner worlds and beings. In this sense, then, ([26], p. 5) "Religious practices and rituals provide the protective cognitive scaffolding to promote integration of all kinds of cognitive and emotional content in such a way as to put that content into the service again of the executive or agentive Self." Having an ascending hierarchy of possible selves is very much what we find - with variations - in many of the Vaiṣnava Sahajiyā texts I have translated over the years. And while metaphor theory and conceptual blending theory can help me to understand the language and tropes much better, McNamara might provide the "cognitive scaffolding" to explain why these esoteric and transgressive practices have proven to be so powerful and enduring over the history of South Asian religions.

The Vaiṣnava Sahajiyās, like most Hindu Tantrics, were always opposed to the caste system, or any attempt to categorize human beings in any terms other than the quality of the inner self. They might agree with McNamara's point that ([26], p. 6): 
The Self is a tool that is specialized for accessing and orchestrating skills and processing resources and knowledge domains in service to the individual. Selves can access, create, orchestrate and realize new human capacities and powers. They should be seen, in part, as tools or perceptual devices created by cultural beliefs and practices and put in service to an individual such that that individual can vastly increase his cognitive and behavioral capacities. Insofar as religion is about individuals, it can be seen as an exquisitely attuned set of cultural practices that assist Selves in the process of creating new human cognitive powers and capacities.

This process of a hierarchy of ascending "possible selves" culminating in the pure agency of an Executive Self can be found in a Vaiṣnava Sahajiyā text which I recently published [15]. Called the Atmatattva or "The Metaphysics of the Selves", this anonymous short text from the early 17 th century brings together notions from Patañjalin Yoga, the erotic aesthetics of Gauḍiya Vaiṣnava theology and dramaturgy, as well as Sāṃhya philosophy and the transgressive sexual ritual practices of Tantra.

Although readers are directed to the published version for a fuller description of the levels of Self in the Atmatattva, here we can note that the text makes extensive use of pentads (as do other South Asian texts), and thus there are five ascending levels of Selves: (1) the "Living Self" (jīvātmā); (2) the "Elemental Self" (bhütātmā); (3) the "Supreme Self" (paramātmā); (4) the "Delight in Knowing the Self" (ätmārāma); and (5) the "Lord Who Delights in Knowing the Self" (ätmārāmeśvara). In terms of McNamara's system, the "Living Self" is the ordinary old Self that we typically inhabit, while the higher four are increasingly agentive, executive, and capable of greater cosmic awareness. I will include a section from my translation to give you a sense of how complex this system is, and how it very much connects to the senses and agency ([15], pp. 236-37):

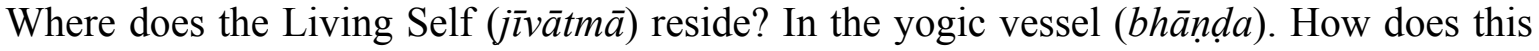
yogic vessel come to be? It develops from the basic building blocks of the universe (tattvavastu). What, then, are these building blocks? Five elements (bhüta) constitute the Self $(\bar{a} t m \bar{a})$ What are these five elements that make up the Self called? The five are earth (prthivi) $)$, water ( $\bar{a} p a)$, fire (teja), air ( $v \bar{a} y u)$, and space ( $\left.\bar{a} k \bar{a} s{ }^{\prime} a\right)$. How might the Living Self be brought under control? [By experiencing] everything from greed (lobha) to liberation (mukti). How might the Elemental Self (bhūtātmā) be brought under control? By sādhana! And what is the sâdhana? Adopting the moods and experiences of a young maiden (sakhi-bhāva-äśraya). The most fundamental sādhana hinges initially on the foundation of the Verses of the Seed-Syllable of Desire (kāma-bija gāyatrī). How is the Supreme Self (paramātmā) to be brought under control? Through sädhanas involving the names of Kṛṣna (nāma) and by mantras. If one combines the names with their corresponding seed-syllables (bija), the Supreme Self can be brought under control. How may the Delight in Knowing the Self (ātmārāma) be controlled? By deep meditation (dhyāna). What is the sādhana of the Delight in Knowing the Self? It includes eight things: food (āhära), sleep (nidrā), cognition (cintā), music (sanīita), thought (manana), worship (bhajana), infatuation (mohana), and modesty (lajjā). What is the sādhana that gives voice (svara) to the Delight in Knowing the Self? The qualities of the Pure Love (prema) for Kṛșna. By pursuing lust ( $k \bar{a} m \bar{a} n u g \bar{a})$, one tastes the ultimate experience of love, starting with eroticism 
(śrngāra), and the rest. Where does the Living Self reside? It dwells in a four-petalled lotus in the "hidden land" near the anus (guhyadeśa). Where does the Elemental Self reside? It dwells at the base of the penis (linga), in a six-petalled lotus. Where does the Supreme Self reside? In a ten-petalled lotus, which is in the place of the Coiled One (kundali $)$. Each petal of that lotus in turn has twelve petals. Where does the Lord Who Delights in Knowing the Self (ätmārāmeśvara) reside? In the place of the blazing (ujjvala) lotus. Each petal there has sixteen petals. Such are the locations of these five lotuses. What is the nature of these five Selves in the five lotuses, and what functions (karmas) do they perform? Furthermore, what is their appearance ( $\bar{a} k \bar{a} r a)$ and what sustains ( $\bar{a} h \bar{a} r a)$ them? What is the appearance of the Living Self? It is blood-red (raktavarna) in color, and it is sustained by water (jala). Its function is the bearing of burdens (bhäravahana). What is the appearance of the Elemental Self? It is bright yellow (haritälvarna) in color, and it is sustained by great quantities of food (āhāra bahu bakșaṇa). Its function is bringing about the understanding (buddhikarana) of the six vices (ripu). What are the names of these six vices? They are desire (kāma), anger (krodha), greed (lobha), infatuation (moha), intoxication (mada), and malice (mätsarya) - these are the six vices. How do these six vices function? They animate (cetana) the senses (indriya). What is the appearance of the Supreme Self? It is the color of lightning (vidyutt), and it is sustained by the wind (vāyu). What is its function? Its function is controlling the various mental states (cinta). What is the appearance of the Delight in Knowing the Self? It is the color of the moon, and it is sustained by the nectar of the stories of Kṛnna. Its function is joyful speech, and always keeping it foremost in one's mind. What is the appearance of the Lord Who Delights in Knowing the Self? It has the form of the sun. It is sustained by the nectar of the sacred stories (kathāmrta). Its tasks (kārya) are the worship (bhajana) of Kṛ̣na, as well as cognition (buddhi), strength (bala), knowledge (jũāna), and the tasting of Divine Essence (rasa āsvādana). These are all of the functions of the five Selves.

Although there are obviously many details in this passage that deserve discussion, it is key for our purposes now to recognize the repeated goal of "controlling" each of the five Selves (regarded as ascending levels of ontological awareness), culminating in the Ideal or Executive Self, quite aptly named the "Lord Who Delights in Knowing the Self". For Vaiṣnava Sahajiyās, this would be identified with the Sahaja-mānuṣa (as mentioned earlier), and the term continues glosses from the earlier Gauḍiya Vaiṣnava notion of Kṛ̣na as the Supreme Godhead, relishing the divine love (prema) of his devotees, especially Rādhā. But also notable are the many references to bodily states, emotions, and cognition. The Vaiṣnava Sahajiyā system very much brings together Gallagher's concepts of body image and body schema, as well as McNamara's notion of "possible selves", transformation via "decentering", and achievement of a unified Executive Self. McNamara also brings in the notion of body schema when he states, regarding his own model of the Self ([26], p. 24):

The Self as a collection of schemas is rooted in work on representational and information-processing properties of the self-concept (e.g., [28]) and the Self as story is rooted in the tradition of narrative psychology (e.g., [29,30]. Both of these metatheories 
contribute to two subtheories of the Self that I will be relying on throughout the book: the theory of self-regulation and the theory of possible selves.

Self-regulation via asceticism and tantric yogic practices, of course, is central to Vaiṣnava Sahajiyā sādhana, as is mastery of the hierarchy of "possible selves". The basic practice of a ropa-sādhana entails the transformation of the worldly body/rüpa of the male and female adepts into the divine inner bodies or svarūpa of Kụṣna and Rādhā. In the Necklace of Immortality the ascent may also involve the mastery of a series of four interior "lotus ponds" (sarovara). These are not the better-known cakras of most Hindu Tantric schools, but are interior holding-ponds of yogically-reversed sexual fluids which the male adept draws into his body through the urethra, a practice known a "reverse practice" (ultā-sādhana) and which has been well studied by David Gordon White [31,32]. From lowest to highest the four ponds, whose names suggest the Vaiṣnava transformation of worldly love into divine love are: (1) the Pond of Lust (kāma-sarovara); (2) the Pond of Arrogance (mana-sarovara); (3) the Pond of Pure Love (prema-sarovara); and finally (4) the Pond of Immortality (aksaya-sarovara). Some selected passages from the Necklace of Immortality state ([14], p. 321):

57 That Place of the Hidden Moon is reached by joining the two principles together. Behold how all the regions of the vast cosmos emerge in that special place.

96 The Pond of Lust is reached through the ninth door of the human body. This is a subject which has been revealed by all the holy books.

97 There are four Ponds within the body: the Pond of Lust, the Pond of Arrogance, the Pond of Divine Love, and the Pond of Immortality.

98 The four Ponds exist within the human heart. If you have a physical body, you can reach the other shores of reality.

99 The Pond of Lust is the most sought after thing of all. Without fail, you must keep performing your practices.

It is interesting how this sequence adapts the orthodox Gaudīya Vaiṣnava narrative process of transforming the lower level of sexual lustful love ( $k \bar{a} m a)$, through the arrogant pique of lovers, and into pure spiritual love (prema; based upon the basic tropes from the Krșnna-līlā stories). However, this process culminates, for Vaiṣnava Sahajiyās, in a transcendent realm beyond the highest heaven called "The Place of the Hidden Moon" (guptacandrapur; see [4]), not in the Gauḍiya Vaiṣnava bhakti experience of Kṛṣṇa -līlā in Nitya-Vṛndāvana.

\section{Conclusions}

I plan on having much more to say about McNamara's approach in a forthcoming essay. As I only have limited space here, I will conclude with a brief overview of his model of the pivotal process of "decentering", the "taking offline" of a lower Self which allows for eventual acquisition of the unified Ideal or Executive Self. McNamara has identified four stages of decentering ([26], pp. 46-47), all of which might be found in some way in Vaiṣnava Sahajiyā sādhana. In the first stage, the sense of agency or volition of the old Self is inhibited through various means. Asceticism and ritual, for example, would be useful here. In the second stage, the Self-structure or Self-concept is placed into what he terms a "suppositional logical space" or a "possible world" box. Again, this is precisely what 
Vaiṣnava Sahajiyās are doing when they move from one Self to the next, or from the physical body/rüpa to the yogic body/svarūpa via arropa-sädhana. For example, the sequence of "possible worlds" could certainly apply to the system of four ascending sarovara or "ponds" in the Necklace, or to the system of the five lotuses (padma) in the Atmatattva. ${ }^{6}$ The third stage consists of a "discrepancy reduction process", where the gap between the current and the Ideal Self is reduced. This may be implemented via ([26], p. 47) "a search of semantic memory to find a more integral version of the Self that can encompass deeper, more optimal solutions to internal and external conflicts and problems". For Vaiṣnava Sahajiyās and Gauḍiya Vaiṣnavas, this search would take them to their many sacred texts or to the oral instructions of their gurus. There are incredibly rich narrative traditions descending from orthodox Vaiṣnavism, Hindu and Buddhist Tantra, and the lineages of the Siddhācāryas (see [31,32]). Finally, the fourth stage is when ([26], p. 47): "The old Self is then bound to and integrated into the new identity (Ideal Self) chosen by the search process via integration of the old story into the new story. If all goes well, that new identity is larger and more complex than the older Self, and thus it is more unified." Here, of course, for Vaiṣnava Sahajiyās the ultimate state of the Sahaja-mānuṣa is achieved, wherein all dualities merge and collapse into the unified state of the "together-born Being."

There is much more, of course, to McNamara's book and to his direction of research, but I trust that in this essay I have demonstrated some promising uses of recent CSR and neuroscience for the study of some very interesting old writings about being a human being. In closing, I was struck by a passage in Michael O'Shea's The Brain: A Very Short Introduction ([34], p. 84): “Memory requires the brain to be physically altered by experience and it is this remarkable property that makes thought, consciousness, and language possible." My own ongoing encounters with the study of religion and of neuroscience are certainly reshaping my own brain, and I look forward to many more years of this remarkable property and ongoing change. All things are intriguingly impermanent!

\section{Conflict of interests}

The author declares no conflict of interest.

\section{References}

1. Glen Alexander Hayes. "Tantra.” Available online: http://www.oxfordbibliographies.com/view/ document/obo-9780195399318/obo-9780195399318-0090.xml (accessed on 24 June 2014).

2. Tony K. Stewart. The Final Word: The Caitanya-caritāmrta and the Grammar of Religious Tradition. New York: Oxford University Press, 2010.

3. Glen Alexander Hayes. "Shapes for the Soul: A Study of Body Symbolism in the Vaiṣnava-sahajiyā Tradition of Medieval Bengal." Ph.D. dissertation, University of Chicago, June 1985.

\footnotetext{
6 It needs to be emphasized that there are numerous different "models" of the cakras and other "vital centers" throughout Hindu and Buddhist Yoga and Tantra. Although the school of Mukunda-deva generally has four ponds, in other traditions of Hindu Tantra we find more than the typical "six plus one" model of cakras so dominant in modern schools of yoga instruction. See [33].
} 
4. Edward C. Dimock, Jr. The Place of the Hidden Moon: Erotic Mysticism in the Vaishnavasahajiyā Cult of Bengal. Chicago: Phoenix Books, 1989.

5. Ramakanta Chakravarti. Vaiṣnavism in Bengal: 1486-1900. Calcutta: Sanskrit Pustak Bhandar, 1985.

6. Manindramohan Basu (Bose). Sahajiyā sāhitya. Calcutta: University of Calcutta, 1932.

7. Manindramohan Bose. The Post-Caitanya Sahajia [sic] Cult of Bengal. Delhi: Gian Publishing House, 1986.

8. Shahshibhusan Dasgupta. Obscure Religious Cults, 3rd ed. Calcutta: Firma K. L. Mukhopadhyay, 1969.

9. Carol Salomon. "The Bāuls.” In Religions of India in Practice. Edited by Donald S. Lopez. Princeton: Princeton University Press, 1995, pp. 187-208.

10. Jeanne Openshaw. Seeking Bāuls of Bengal. New York: Cambridge University Press, 2002.

11. Hugh B Urban. The Economics of Ecstasy: Tantra, Secrecy, and Power in Colonial Bengal. New York: Oxford University Press, 2001.

12. Hugh B Urban. Songs of Ecstasy: Tantric and Devotional Songs from Colonial Bengal. New York: Oxford University Press, 2001.

13. Glen Alexander Hayes. "The Vaiṣnava Sahajiyā Traditions of Medieval Bengal." In Religions of India in Practice. Edited by Donald S Lopez. Princeton: Princeton University Press, 1995, pp. 333-51.

14. Glen Alexander Hayes. "The Necklace of Immortality: A 17th-Century Vaiṣnava Sahajiyā Text." In Tantra in Practice. Edited by David Gordon White. Princeton: Princeton University Press, 2000, pp. 308-25.

15. Glen Alexander Hayes. "Eroticism and Cosmic Transformation as Yoga: The Atmatattva of the Vaiṣnava Sahajiyās of Bengal.” In Yoga in Practice. Edited by David Gordon White. Princeton: Princeton University Press, 2012, pp. 223-41.

16. George Lakoff, and Mark Johnson. Metaphors We Live By. Chicago: University of Chicago Press, 1980.

17. Gilles Fauconnier, and Mark Turner. The Way We Think: Conceptual Blending and the Mind's Hidden Complexities. New York: Basic Books, 2002.

18. Glen Alexander Hayes. "Conceptual Blending Theory, 'Reverse Amnesia', and the Study of Tantra." Oxford Journal of Hindu Studies 5 (2012): 193-209.

19. Kelly Bulkeley. The Wondering Brain: Thinking about Religion with and beyond Cognitive Neuroscience. New York: Routledge, 2004.

20. Kelly Bulkeley, ed. Soul, Psyche, Brain: New Directions in the Study of Religion and Brain-Mind Science. New York: Palgrave MacMillan, 2005.

21. Shaun Gallagher. How the Body Shapes the Mind. New York: Oxford University Press, 2005.

22. Mark Johnson. The Body in the Mind: The Bodily Basis of Meaning, Imagination, and Reason. Chicago: University of Chicago Press, 1987.

23. David Haberman. Acting as a Way of Salvation: A Study of Rāgānugā Bhakti Sādhana. New York: Oxford University Press, 1988.

24. James R. Lackner. "Some proprioceptive influences on the perceptual representation of body shape and orientation." Brain 3 (1988): 281-97. 
25. Edward Slingerland. What Science Offers the Humanities: Integrating Body and Culture. New York: Cambridge University Press, 2008.

26. Patrick McNamara. The Neuroscience of Religious Experience. Cambridge: Cambridge University Press, 2009.

27. Edward C. Dimock, Jr., and Tony K. Stewart. Caitanya Caritāmṛta of Kṛșnadāsa Kavirāja: A Translation and Commentary. Edited by Michael Witzel. Cambridge: Department of Sanskrit and Indian Studies, Harvard University, 1999.

28. Hazel Markus. "Self-schemata and information about the Self." Journal of Personality and Social Psychology 35 (1977): 63-78.

29. Jerome S. Bruner. Acts of Meaning. Cambridge: Harvard University Press, 1990.

30. Dan P. McAdams. "Personality, modernity, and the storied self: A contemporary framework for studying persons." Psychological Inquiry 7 (1996): 295-321.

31. David Gordon White. The Alchemical Body: Siddha Traditions in Medieval India. Chicago: University of Chicago Press, 1996.

32. David Gordon White. Kiss of the Yoginī: "Tantric Sex" in its South Asian Contexts. Chicago: University of Chicago Press, 2003.

33. David Gordon White. "Yoga in Early Hindu Tantra." In Yoga: The Indian Tradition. Edited by Ian Whicher and David Carpenter. New York: Routledge, 2003, pp. 143-61.

34. Michael O'Shea. The Brain: A Very Short Introduction. London: Oxford University Press, 2005.

(C) 2014 by the author; licensee MDPI, Basel, Switzerland. This article is an open access article distributed under the terms and conditions of the Creative Commons Attribution license (http://creativecommons.org/licenses/by/3.0/). 